\title{
Inadequate corporate profitability and marketability efficiency: A case of Vietnam manufacturing enterprises
}

\author{
$\underline{\text { D. L. T. } A n h}^{\mathrm{a}}$ (i) and C. Gan ${ }^{\mathrm{a}}$ \\ ${ }^{a}$ Faculty of Agribusiness and Commerce, Lincoln University, New Zealand \\ Email:1e.dao@lincolnuni.ac.nz
}

\begin{abstract}
The manufacturing sector plays an increasingly pivotal role in the development of Vietnam. In the context of economic integration, Vietnam manufacturing enterprises receive abundant investment and market-expansion opportunities that enhance their operating profits and market values. With the aim of supporting corporate managers to position their firms competitively in the market as well as make wise management decisions, this study employs bootstrap two-stage data envelopment analysis technique to investigate the profitability and marketability efficiency of 102 listed manufacturing firms on Vietnam stock market from 2007 to 2018 . The study also applies fractional regression models for panel data to identify the determinants of Vietnam manufacturing firms' efficiencies.

Based on the empirical results, the study reveals that Vietnam manufacturing firms obtain higher profitability efficiency scores $(0.888)$ than marketability efficiency scores $(0.527)$ during the study period from 2007 to 2018. Thus, listed manufacturing enterprises in Vietnam should place more emphasis on market attractiveness to boost their enterprises' market value. Besides, different manufacturing sub-sectors achieve different levels of profitability and marketability efficiency during the study period 2007 to 2018. Specifically, the modern (high-tech) firms achieve higher average marketability efficiency scores from 2007 to 2018 and better profitability efficiency performance in the recent years from 2015 to 2018 than the traditional (resourceintensive and labour-intensive) manufacturing firms. The results also show the diverse and significant impacts of firm age, headcount, institutional ownership, cash level, and leverage ratio on profitability and marketability efficiency of Vietnam manufacturing enterprises.
\end{abstract}

Keywords: Bootstrap two-stage DEA, Fractional regression model, Vietnam manufacturing sector 


\section{INTRODUCTION}

The manufacturing sector has contributed significantly to Vietnam economic growth recently. The World Bank (2019) statistic shows the percentage of exported manufacturing products over Vietnam total exported commodities increased from $44 \%$ in 1997 to $83 \%$ in 2017 . With the competitive advantages of low employment costs, large consumer population, better investment policies and improving infrastructure conditions, Vietnam is considered as one of the most attractive destinations in Southeast Asia to reallocate manufacturing operations from China (Lim, 2017).

The introduction of ASEAN Economic Community (AEC) by members of Association of Southeast Asian Nations (ASEAN) including Vietnam in 2015 is a milestone for the development of Vietnam's manufacturing industries. AEC is oriented to become a manufacturing and trading hub that is resilient and highly integrated into the global economy (ASEAN, 2015). Following the AEC's establishment and provisions, Vietnam's manufacturing enterprises have favourable conditions to attract more investors, raise more funds and widen their markets' opportunities in the region.

Corporates' profitability and marketability efficiency are the two important measurements reflecting firms' operation and financial success. The profitability of a business is defined as an ability to gain its income, while marketability is the capability to trade securities in the market. Thus, a business's profitability efficiency is an important measurement for internal operation results. Marketability efficiency, on the other hand, is a critical proxy that displays how the external market assesses real business's value (Hung and Wang, 2012). Understanding the efficiency levels of the firms will help corporate managers to position their firms competitively in the market as well as make wise management and investment decisions. Profitability and marketability efficiency are investigated widely for developed markets in the literature, but limited studies have been conducted on Vietnam in the same sphere. In addition, the impacts of financial and non-financial characteristics on the profitability and marketability efficiency of Vietnamese firms have not been investigated.

This study provides an assessment of manufacturing firms' profitability and marketability efficiency in Vietnam. The study explores the effects of financial and non-financial characteristics on Vietnam manufacturing enterprises' earnings and market-value efficiency. Furthermore, the study divides manufacturing firms into three manufacturing sub-sectors based on the industries' production characteristics to compare the efficiency levels of firms in different manufacturing sub-sectors and identify the factors that significantly affect their profit and market valuation efficiency.

\section{NON-PARAMETRIC AND PARAMETRIC RESEARCH APPROACHES}

This study consists of two analytical steps: Step 1 uses a non-parametric method, that is the bootstrap twostage Data Envelopment Analysis (bootstrap 2S-DEA) to evaluate Vietnam listed manufacturing firms' efficiency levels. Step 2 adopts Fractional Regression Model (FRM), a parametric approach to assess the influences of financial and non-financial factors on firms' DEA efficiency scores.

In step 1, the firms' profitability and marketability efficiency are measured by the 2S-DEA process adapted from Seiford and Zhu (1999), Hung and Wang (2012) and modified as in Figure 1. In each stage of the 2SDEA method, an application of the bootstrap technique to calculate corporate technical efficiency is implemented.

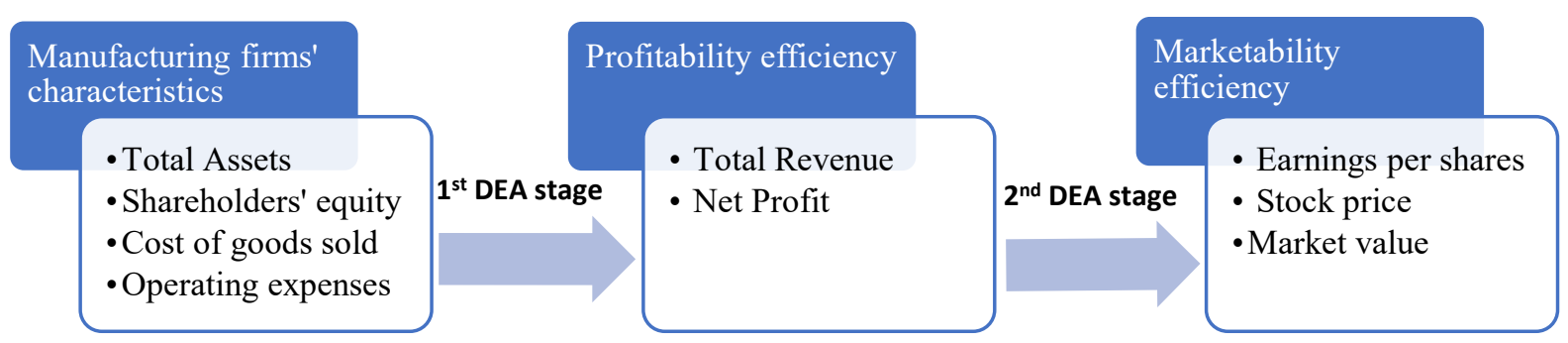

Figure 1. Bootstrap 2S-DEA process to measure profitability and marketability efficiency of manufacturing firms in Vietnam

In step 2, the study employs FRM for panel data (Ramalho et al., 2016) to examine the impacts of financial and non-financial characteristics of Vietnam manufacturing enterprises' profitability and marketability efficiency scores obtained from the bootstrap 2S-DEA method. Fractional Regression Model (FRM) is the 
preferred method for examining DEA scores' determinants in recent studies. The characteristic of DEA scores is not censored and truncated but a natural result from the DEA approach. FRM is able to handle the nature of the dependent variable (DEA scores) that takes the value inside the interval $(0,1)$, regardless of the availability of observed frontier values. According to Ramalho et al. (2010) and Gallani et al. (2015), FRM is the most advantageous model for continuous data with values bounded from 0 to 1 .

Ramalho et al. (2016) propose a general regression model regarding the fractional nature of response variables as equation (1):

$$
y_{i t}=G\left(x_{i} \theta+\beta_{i}+\vartheta_{i t}\right)
$$

Where $\vartheta_{i t}$ represents the time-differing unrecognised heterogeneity, while G(.) is presumed to be a functional specification such as logit, probit, loglog or cloglog.

Ramalho et al. (2016) then adopt the link function $H\left(y_{i t}\right)=G(.)^{-1}$ to generate a simple linear-fractional regression model to examine as equation (2):

$$
H\left(y_{i t}\right)=x_{i} \theta+\beta_{i}+\vartheta_{i t}
$$

Ramalho et al. (2016) apply four standard functional specification forms (logit, probit, loglog, and cloglog) to define $H\left(y_{i t}\right)$ as in table 1 .

Table 1. Specification forms of linear FRM for panel data (Ramalho et al., 2016)

\begin{tabular}{|c|c|c|}
\hline Forms of linear FRM & $G()$. & $H\left(y_{i t}\right)$ \\
\hline Logit & $G()=.\exp () /.[1+\exp ()]$. & \begin{tabular}{l}
$\ln \left[\frac{y_{i t}}{1-y_{i t}}\right]$ \\
\hline Probit
\end{tabular} \\
\hline Loglog & $\varphi()$. & $\begin{array}{c}\text { invnor } \varphi\left(y_{i t}\right) \\
\text { invnor } \varphi: \text { inversely cumulated normal } \\
\text { distribution }\end{array}$ \\
\hline Cloglog & $\exp \{-\exp [-()]\}$. & $-\ln \left[-\ln \left(y_{i t}\right)\right]$ \\
\hline & $G()=.1-\frac{\exp (.)}{[-\exp (.)]}$ & {$\left[-\ln \left(1-y_{i t}\right)\right]$} \\
\hline
\end{tabular}

This study estimates two FRM models: Model FRM1 examines the determinants of corporate profitability efficiency and model FRM2 investigates the factors that affect firm marketability efficiency. Based on previous literature, this study evaluates the impacts of both financial factors (such as level of cash and leverage) and non-financial factors (such as firm age, number of staffs and institutional ownership) on firm efficiency levels. The fractional regression models FRM1 and FRM2 are generalised as follows:

$$
\begin{array}{ll}
H\left(P R O \_E F\right)=f_{1}(A G E ; C A S H ; S T A F F ; L E V E R A G E ; \text { INSTIT) } & \text { (FRM1) } \\
H\left(M R K \_E F\right)=f_{2}(A G E ; C A S H ; S T A F F ; L E V E R A G E ; I N S T I T) & \text { (FRM2) }
\end{array}
$$

Table 2 defines the variables used in models FRM1 and FRM2:

Table 2. Clarification of variables presented in model FRM1 and FRM2

\begin{tabular}{|l|l|}
\hline \multicolumn{1}{|c|}{ Variables } & \multicolumn{1}{c|}{ Definition } \\
\hline$H\left(P R O F_{-} E F\right)$ & $\begin{array}{l}\text { Functional form (logit, probit, loglog, cloglog) of profitability efficiency scores measured } \\
\text { from bootstrap 2S-DEA method }\end{array}$ \\
\hline$H\left(M R K_{-} E F\right)$ & $\begin{array}{l}\text { Functional form (logit, probit, loglog, cloglog) of marketability efficiency scores measured } \\
\text { from bootstrap 2S-DEA method }\end{array}$ \\
\hline$A G E$ & Number of years that the firm is listed in the stock market \\
\hline$C A S H$ & Represents liquidity, that is, the percentage of cash over total assets \\
\hline$S T A F F$ & Number of corporate staffs \\
\hline$L E V E R A G E$ & Represents capital structure, that is, the percentage of total liabilities over total assets \\
\hline$I N S T I T$ & Represents the percentage of institution-owned shares of the firm \\
\hline
\end{tabular}


Finally, following Badunenko et al. (2006) who argue that industry characteristics affect firms' efficiency levels, this study classifies Vietnam manufacturing firms into sub-sectors to determine if there is any difference in efficiency levels as well as their determinants among various manufacturing industries.

\section{DATA COLLECTION AND CATEGORISATION}

The study collects annual data of 102 manufacturing firms listed on Vietnam stock market over twelve years from 2007 to 2018. All data are extracted from Bloomberg and Vietnam manufacturing firms' annual reports. Based on the manufacturing industries' production characteristics in Vietnam, the study categorises 102 manufacturing firms into the three sub-sectors (see Table 3).

Table 3. Vietnam manufacturing sub-sectors' classification, number of firms investigated and list of tickers

\begin{tabular}{|c|c|c|c|c|}
\hline $\begin{array}{l}\text { Sub- } \\
\text { sector } \\
\text { ticker }\end{array}$ & $\begin{array}{c}\text { Name of } \\
\text { manufacturing } \\
\text { sub-sector }\end{array}$ & List of manufacturing industries & $\begin{array}{l}\text { Number of } \\
\text { firms } \\
\text { investigated }\end{array}$ & $\begin{array}{l}\text { Bloomberg's VN Equity tickers of } \\
\text { investigated firms }\end{array}$ \\
\hline S1 & $\begin{array}{l}\text { Global technology } \\
\text { application }\end{array}$ & $\begin{array}{l}\text { - Chemicals, pharmaceuticals } \\
\text { - Computers, machinery, motor } \\
\text { vehicles and equipment }\end{array}$ & 15 & $\begin{array}{l}\text { DHG; DMC; HAI; IMP; PAC; PLC; POT; } \\
\text { PVC; RAL; REE; SAM; SFN; TST; TYA; } \\
\text { UNI }\end{array}$ \\
\hline $\mathrm{S} 2$ & $\begin{array}{l}\text { National resource- } \\
\text { intensive } \\
\text { production }\end{array}$ & $\begin{array}{ll}\text { - } & \text { Coke and refined petroleum } \\
\text { products } \\
\text { - } \\
\text { Metallic and non-metallic } \\
\text { mineral products } \\
\text { - } \text { Rubber and plastics products } \\
\text { - Wood, paper products, } \\
\text { recycling products }\end{array}$ & 44 & $\begin{array}{l}\text { BBS; BCC; BMP; BPC; BT6; BTS; CLC; } \\
\text { CTB; DNP; DPC; DPR; DRC; DTT; HAP; } \\
\text { HCC; HLY; HPG; HRC; HT1; L10; LBM; } \\
\text { MCP. MEC; NBC; NHC; NTP; S55; SCJ; } \\
\text { SDN; SMC; STP; TAC; TCM; TCR; TKU; } \\
\text { TNC; TPC; TRC; TTC; TXM; VCS; VIS; } \\
\text { VPK; VTS }\end{array}$ \\
\hline $\mathrm{S} 3$ & $\begin{array}{l}\text { National labour- } \\
\text { intensive } \\
\text { production }\end{array}$ & $\begin{array}{ll} & \text { Textiles, leather and footwear } \\
\text { - } & \text { Printing and publishing } \\
\text { - } & \text { Food, beverages and tobacco } \\
\text { - } & \text { Furniture and household goods } \\
\text { - } & \text { Other unclassified } \\
& \text { manufacturing industries }\end{array}$ & 43 & $\begin{array}{l}\text { ABT; ACL; AGF; ANV; BBC; CAN; DAE; } \\
\text { DCS; DPM; DST; EBS; FMC; GIL; GMC; } \\
\text { GTA; HEV; HHC; HNM; HTP; KDC; LAF; } \\
\text { NAV; NSC; NST; PNC; SAF; SAP; SAV; } \\
\text { SCD; SGC; SGD; SJ1; SSC; TNG; TPH; } \\
\text { TS4; TSC; VDL; VHC; VID; VNM; VTB; } \\
\text { VTL }\end{array}$ \\
\hline \multicolumn{3}{|r|}{ Total } & 102 & \\
\hline
\end{tabular}

Source: Manufacturing industries classification adapted from OECD (2011)

\section{RESEARCH FINDINGS}

\subsection{Bootstrap 2S-DEA process results}

Based on the bootstrap 2S-DEA technique, we obtain the profitability and marketability efficiency scores of individual Vietnamese listed firms in the manufacturing sector and three sub-sectors: global technology application (sub-sector S1), national resource-intensive production (sub-sector S2), and national labourintensive production (sub-sector S3). The average scores of Vietnamese firms in the manufacturing sector and each sub-sector are reported in Table 4.

Table 4. Profitability and marketability efficiency scores of Vietnam manufacturing listed firms from 2007 to 2018

\begin{tabular}{|l|r|r|r|r|}
\hline & \multicolumn{1}{|c|}{ All sector } & Sub-sector S1 & Sub-sector S2 & \multicolumn{1}{c|}{ Sub-sector S3 } \\
\hline Profitability efficiency & 0.888 & 0.885 & 0.893 & 0.884 \\
\hline Marketability efficiency & 0.527 & 0.553 & 0.499 & 0.545 \\
\hline
\end{tabular}

Table 4 shows the average profitability efficiency score of Vietnam manufacturing firms is 0.888 over 12 years. The levels of firms' profitability efficiency in the manufacturing sector and each sub-sector decrease from 2007 to 2009, increase from 2009 to 2013 and decrease from 2013 to 2018 (see Figure 2). While sub-sector S2 (resource-intensive) and S3 (labour-intensive) display a similar trend with the manufacturing sector during the period 2007 - 2018, sub-sector S1 (high-tech) shows a different movement. Sub-sector S1 also gets better results than the two other sectors from 2015 to 2018. 
Anh et al., Profitability and marketability efficiency of Vietnam manufacturing firms

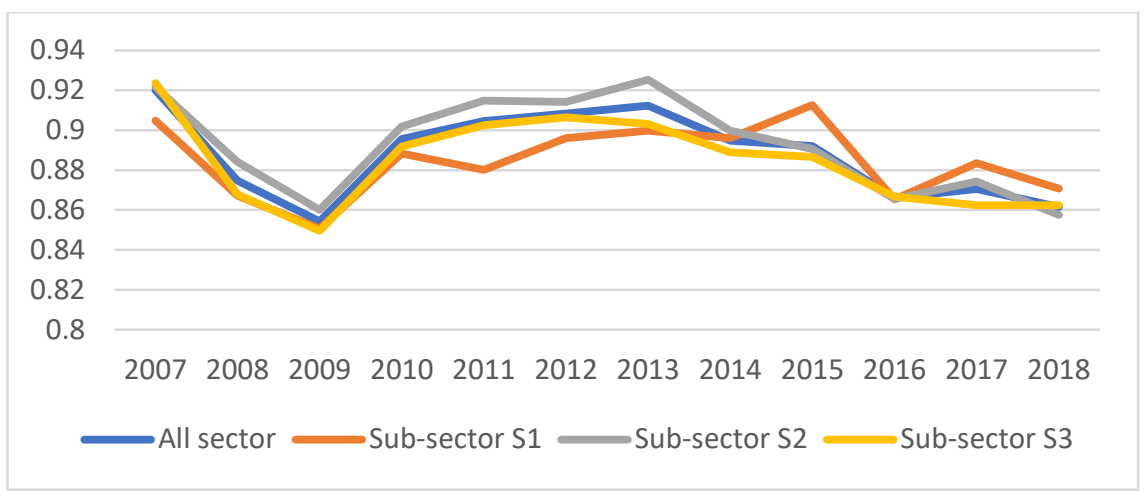

Figure 2. Profitability efficiency of Vietnam manufacturing listed firms from 2007 to 2018

In comparison with profitability efficiency, the marketability efficiency scores of Vietnam listed manufacturing firms are significantly lower (the average score of marketability efficiency for all firms over the 12 years is 0.527). Moreover, there is no considerable improvement in the marketability efficiency levels for all the manufacturing sector over time from 2007 through 2018 (see Figure 3). Comparing among the three subsectors, sub-sector S1 (high-tech) obtains the highest average marketability efficiency scores over time. The efficiency performance of this sector is also better than the two other sectors in recent years from 2016 to 2018. Even though sub-sector S2 (resource-intensive) achieves the highest level of profitability efficiency between 2007 and 2018, the average marketability efficiency score of this sector is lower than the two other sub-sectors.

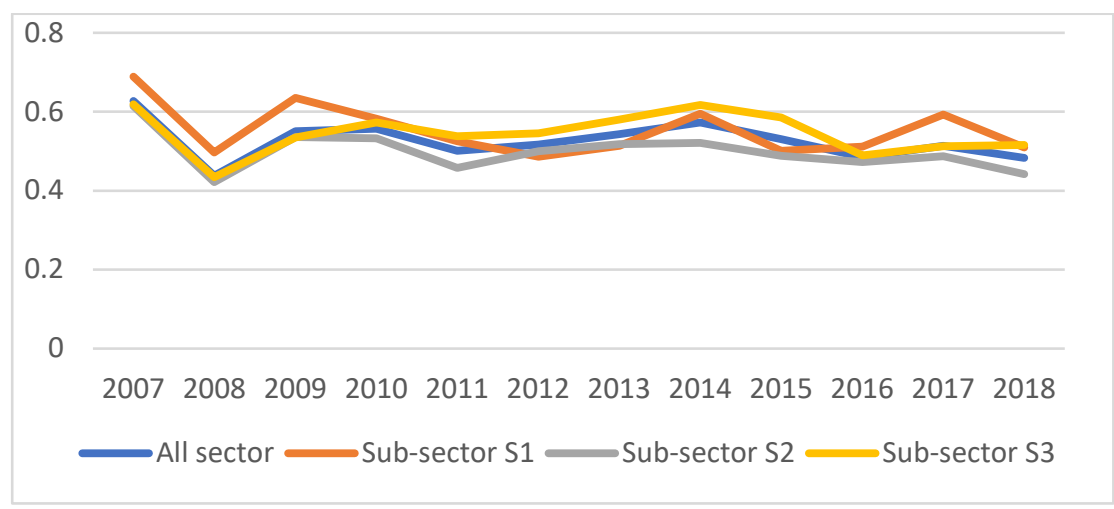

Figure 3: Marketability efficiency of Vietnam manufacturing listed firms from 2007 to 2018

\subsection{FRM results}

Tables 5 and 6 display the FRM results of Models FRM1 and FRM2, which evaluate the effects of financial and non-financial factors on firms' profitability and marketability efficiency scores in Vietnam manufacturing sector and sub-sectors S1 (high-tech), S2 (resource-intensive), and S3 (labour-intensive).

Table 5. FRM results for model FRM1 (profitability efficiency)

\begin{tabular}{|l|c|c|c|c|}
\hline $\begin{array}{c}\text { Profitability } \\
\text { efficiency }\end{array}$ & $\begin{array}{c}\text { Manufacturing } \\
\text { sector }\end{array}$ & $\begin{array}{c}\text { Sub-sector } \\
\text { S1 }\end{array}$ & $\begin{array}{c}\text { Sub-sector } \\
\text { S2 }\end{array}$ & $\begin{array}{c}\text { Sub-sector } \\
\text { S3 }\end{array}$ \\
\hline AGE & - & - & - & - \\
\hline CASH & $\mathrm{n} / \mathrm{s}$ & $\mathrm{n} / \mathrm{s}$ & $\mathrm{n} / \mathrm{s}$ & $\mathrm{n} / \mathrm{s}$ \\
\hline STAFF & + & $\mathrm{n} / \mathrm{s}$ & $+\mathrm{s}$ & + \\
\hline LEVERAGE & + & $\mathrm{n} / \mathrm{s}$ & + & + \\
\hline INSTIT & + & $\mathrm{n} / \mathrm{s}$ & + \\
\hline
\end{tabular}

Note: ' $n / s$ ': not significant; '十' : positive and significant; '-': negative and significant

Table 5 shows AGE variable has a negative relationship with all Vietnam listed manufacturing firms' profitgenerating efficiency, indicating that manufacturing firms in Vietnam tend to be less profitability efficient when they stay longer in the market. In contrast to AGE variable, STAFF, LEVERAGE and INSTIT factors have positive and significant influences on firms' profitability efficiency levels. In other words, the bigger the 
number of employees (STAFF), the higher debt ratio (LEVERAGE) and the larger amount of institutional ownership (INSTIT) bring about better profitability efficiency results of Vietnam listed manufacturing firms.

Table 6. FRM results for model FRM2 (marketability efficiency)

\begin{tabular}{|l|c|c|c|c|}
\hline $\begin{array}{c}\text { Marketability } \\
\text { efficiency }\end{array}$ & $\begin{array}{c}\text { Manufacturing } \\
\text { sector }\end{array}$ & $\begin{array}{c}\text { Sub-sector } \\
\text { S1 }\end{array}$ & $\begin{array}{c}\text { Sub-sector } \\
\text { S2 }\end{array}$ & $\begin{array}{c}\text { Sub-sector } \\
\text { S3 }\end{array}$ \\
\hline AGE & - & $\mathrm{n} / \mathrm{s}$ & $\mathrm{n} / \mathrm{s}$ & - \\
\hline CASH & + & + & $\mathrm{n} / \mathrm{s}$ & $\mathrm{n} / \mathrm{s}$ \\
\hline STAFF & $\mathrm{n} / \mathrm{s}$ & $\mathrm{n} / \mathrm{s}$ & $\mathrm{n} / \mathrm{s}$ & + \\
\hline LEVERAGE & $\mathrm{n} / \mathrm{s}$ & $\mathrm{n} / \mathrm{s}$ & $\mathrm{n} / \mathrm{s}$ & + \\
\hline INSTIT & $\mathrm{n} / \mathrm{s}$ & $\mathrm{n} / \mathrm{s}$ & $\mathrm{n} / \mathrm{s}$ \\
\hline
\end{tabular}

Note: ' $n / s^{\prime}$ ': not significant; '+'? positive and significant; '-': negative and significant

Table 6 reports the heterogeneous impacts of the factors on Vietnam listed manufacturing firms' marketability efficiency levels. Specifically, the results show that AGE variable has a negative relationship with firms' marketability efficiency. This implies the longer the firms listed on the stock market, the lower the marketvalue efficiency the firms obtain. Besides, when firms retain higher levels of cash ratio (CASH), they achieve higher marketability efficiency scores.

\section{CONCLUSIONS AND RECOMMENDATIONS}

Vietnam manufacturing businesses play an influential role in the growth of Vietnam economy in recent years. The establishment of AEC in 2015 has offered numerous promising opportunities for Vietnam manufacturing firms to increase profits and boost their market values. With the purpose of fostering Vietnam manufacturing enterprises' development, we adopt bootstrap 2S-DEA and FRM methods to investigate 102 manufacturing firms listed in Vietnam stock market. The study draws several conclusions and suggestions to enhance the profitability and marketability efficiency of Vietnam manufacturing enterprises as follows:

First, the study reveals that Vietnam manufacturing firms obtain higher profitability efficiency scores $(0.888)$ than marketability efficiency scores (0.527) during the study period 2007 to 2018 . While the profitability efficiency levels of firms alter during the 12 years, the marketability efficiency remains at low levels over time. This implies that listed manufacturing enterprises in Vietnam should place more emphasis on market attractiveness to boost their enterprises' market values.

Besides, different manufacturing sub-sectors achieve different levels of profitability and marketability efficiency during the period 2007 to 2018. This result is consistent with Badunenko et al. (2006)'s findings, which demonstrate that firms in different industries achieve dissimilar efficiency levels. Among three subsectors, sub-sector S1 (high-tech) achieves the best marketability efficiency performance during the 12 years from 2007 to 2018 as well as the highest profitability efficiency from 2015 to 2018 . This finding shows that modern manufacturing firms operate more efficiently than traditional (resource-intensive and labour-intensive) enterprises.

Second, non-financial factors affect Vietnam manufacturing firms' technical efficiency differently.

- There is a reverse relationship between the number of listed years of Vietnam manufacturing firms and their efficiency performance. That is, the more listing experience Vietnam manufacturing firms have, the lower levels profitability and marketability efficiency the firms achieve. According to Agarwal and Gort (1996 and 2002), operating for a long time in the industry may lead the firms to obsolete knowledge and technology. Another reason is that success and experience gradually create inflexible regulations through organisation and processes, which can frame firms in procedure-related rigidities and eventually harm the development of firms (Leonard-Barton, 1992). To deal with this problem, Vietnam listed manufacturing firms need to invest more in research and development as well as marketing activities to improve their internal operations and market-value results.

- The number of staffs affects firms' profitability efficiency positively. This finding supports Schneider (1991)'s research which reveals that large enterprises are inclined to be more efficient than smaller ones based on value-added per staff. Our result implies that Vietnam manufacturing firms may consider increasing the number of employees to enhance profit-generating efficiency.

- The study also finds a positive relationship between institutional ownership and profitability efficiency levels of Vietnam manufacturing firms. This finding is consistent with the conclusions of Shleifer and Vishny (1986) and Tsai and Gu (2007), which conclude that institutional ownership enhances firms' 
performance by alleviating agency issues from authority split, diminishing information asymmetry and supporting firms in terms of financing and experience.

Third, financial factors have diverse impacts on firms' profitability and marketability efficiency in Vietnam manufacturing sector (including sub-sectors).

- Cash levels have a positive relationship with Vietnam manufacturing enterprises' marketability efficiency, thus holding more cash is beneficial for Vietnam manufacturing firms to increase corporate market values. This conclusion is consistent with Singh and Fida (2015) and Edjigu (2016) who demonstrate that liquidity has a significantly positive impact on firms' efficiency levels.

- Regarding the leverage factor, high levels of debts increase all Vietnam listed manufacturing firms' profitability efficiency in general and sub-sector S3 enterprises' marketability efficiency in particular. This result is supported by Margaritis and Psillaki (2007) and Mok et al. (2007), who demonstrate a significantly positive influence of leverage ratio on corporate efficiency levels. Hence, in order to boost Vietnam manufacturing firms' profit and marketability efficiency, increasing the level of debts might be a good financial option.

\section{REFERENCES}

ASEAN (2015). A blueprint for growth. ASEAN Economic Community 2015: Progress and Key Achievements. Retrieved from: http://asean.org/?static_post=asean-economic-community-2015progress-and-key-achievements-2

Badunenko, O., Fritsch, M., Stephan, A. (2006). What Determines the Technical Efficiency of a Firm? The Importance of Industry, Location, and Size (No. 33/2006). Friedrich-Schiller-Universität Jena, Wirtschaftswissenschaftliche Fakultät.

Edjigu, H. T. (2016). Firm Growth and Technical Efficiency in Ethiopia: The Role of Firm Size and Finance. International Journal of Economics and Finance, 8(10), 1-13.

Gallani, S., Krishnan, R., Wooldridge, J. M. (2015). Applications of fractional response model to the study of bounded dependent variables in accounting research. Harvard Business School.

Hung, S. W., Wang, A. P. (2012). Entrepreneurs with glamour? DEA performance characterization of hightech and older-established industries. Economic Modelling, 29(4), 1146-1153.

Leonard-Barton, D. (1992). Core Capabilities and Core Rigidities: A Paradox in Managing New Product Development. Strategic Management Journal, 1, Special Issue: Strategy Process: Managing Corporate Self-Renewal, 111-125.

Lim, R. (2017). A revival of Southeast Asian manufacturing. JLL (Jones Lang LaSalle) report.

OECD (2011). ISIC Rev.3 Technology Intensity Definition. STAN indicator database. Retrieved from: www.oecd.org/sti/stan/indicators

Margaritis, D., Psillaki, M. (2007). Capital Structure and Firm Efficiency. Journal of Business Finance \& Accounting, 34(9-10), 1447-1469.

Mok, V., Yeung, G., Han, Z., Li, Z. (2007). Leverage, Technical Efficiency and Profitability: An application of DEA to foreign-invested toy manufacturing firms in China. Journal of Contemporary China, 16(51), 259-274.Papke, L. E., Wooldridge, J. M. (1996). Econometric methods for fractional response variables with an application to $401(\mathrm{k})$ plan participation rates. Journal of applied econometrics, 11(6), 619-632.

Ramalho, E. A., Ramalho, J. J., Henriques, P. D. (2010). Fractional regression models for second stage DEA efficiency analyses. Journal of Productivity Analysis, 34(3), 239-255.

Ramalho, E. A., Ramalho, J. J., Coelho, L. M. (2016). Exponential regression of fractional-response fixedeffects models with an application to firm capital structure. Journal of Econometric Methods, 7(1).

Seiford, L., Zhu, J. (1999). Profitability and Marketability of the Top 55 U.S. Commercial Banks. Management Science, 45(9), 1270-1288.

Schneider, F. (1991). Efficiency and profitability: An inverse relationship according to the size of Austrian firm? Small Business Economics, 3(4), 287-296.

Singh, D., Fida, B. A. (2015). Technical efficiency and its determinants: An empirical study on banking sector of Oman. Problems and Perspectives in Management, 13(1), 168-175.

Shleifer, A., Vishny, R. W. (1986). Large shareholders and corporate control. Journal of political economy, 94(3, Part 1), 461-488.

The World Bank (2019). Manufactures exports (\% of merchandise exports). Retrieved from https://data.worldbank.org/indicator/TX.VAL.MANF.ZS.UN?locations=VN

Tsai, H., Gu, Z. (2007). The relationship between institutional ownership and casino firm performance. International Journal of Hospitality Management, 26(3), 517-530. 